Atmos. Chem. Phys., 13, 11887-11903, 2013

www.atmos-chem-phys.net/13/11887/2013/

doi:10.5194/acp-13-11887-2013

(c) Author(s) 2013. CC Attribution 3.0 License.

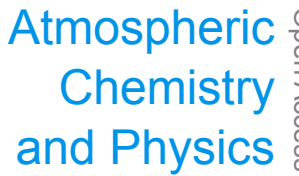

\title{
Analysis of particle size distribution changes between three measurement sites in northern Scandinavia
}

\author{
R. Väänänen ${ }^{1}$, E.-M. Kyrö ${ }^{1}$, T. Nieminen ${ }^{1,2}$, N. Kivekäs ${ }^{3,4}$, H. Junninen ${ }^{1}$, A. Virkkula ${ }^{1,3}$, M. Dal Maso ${ }^{1,5}$, \\ H. Lihavainen ${ }^{3}$, Y. Viisanen ${ }^{3}$, B. Svenningsson ${ }^{4}$, T. Holst ${ }^{6}$, A. Arneth ${ }^{7}$, P. P. Aalto ${ }^{1}$, M. Kulmala ${ }^{1}$, and V.-M. Kerminen ${ }^{1}$ \\ ${ }^{1}$ Department of Physics, University of Helsinki, P.O. Box 64, 00014 University of Helsinki, Helsinki, Finland \\ ${ }^{2}$ Helsinki Institute of Physics, P.O. Box 64, 00014 University of Helsinki, Helsinki, Finland \\ ${ }^{3}$ Finnish Meteorological Institute, Climate Change Unit, 00101 Helsinki, Finland \\ ${ }^{4}$ Lund University, Department of Physics, Lund, 22100 Lund, Sweden \\ ${ }^{5}$ Tampere University of Technology, Dept. of Physics, P.O. Box 692, 33101 Tampere, Finland \\ ${ }^{6}$ Department of Physical Geography and Ecosystems Science, Sölvegatan 12, 22362 Lund, Sweden \\ ${ }^{7}$ Karlsruher Institute of Technology, Instute of Meteorology and Climate Research/Atmospheric Environmental Research \\ (IMK-IFU), Kreuzeckbahnstr. 19, 82467 Garmisch-Partenkirchen, Germany
}

Correspondence to: R. Väänänen (riikka.vaananen@helsinki.fi)

Received: 15 February 2013 - Published in Atmos. Chem. Phys. Discuss.: 9 April 2013

Revised: 18 October 2013 - Accepted: 30 October 2013 - Published: 9 December 2013

\begin{abstract}
We investigated atmospheric aerosol particle dynamics in a boreal forest zone in northern Scandinavia. We used aerosol number size distribution data measured with either a differential mobility particle sizer (DMPS) or scanning mobility particle sizer (SMPS) at three stations (Värriö, Pallas and Abisko), and combined these data with the HYSPLIT (Hybrid Single Particle Lagrangian Integrated Trajectory) air mass trajectory analysis. We compared three approaches: analysis of new particle formation events, investigation of aerosol particle number size distributions during the air mass transport from the ocean to individual stations with different overland transport times, and analysis of changes in aerosol particle number size distributions during the air mass transport from one measurement station to another. Aitkenmode particles were found to have apparent average growth rates of $0.6-0.7 \mathrm{~nm} \mathrm{~h}^{-1}$ when the air masses traveled over land. Particle growth rates during the new particle formation (NPF) events were 3-6 times higher than the apparent particle growth during the summer period. When comparing aerosol dynamics for different overland transport times between the different stations, no major differences were found, except that in Abisko the NPF events were observed to take place in air masses with shorter overland times than at the other stations. We speculate that this is related to the meteorological differences along the paths of air masses caused
\end{abstract}

by the land surface topology. When comparing air masses traveling in an east-to-west direction with those traveling in a west-to-east direction, clear differences in the aerosol dynamics were seen. Our results suggest that the condensation growth has an important role in aerosol dynamics even when NPF is not evident.

\section{Introduction}

High northern latitudes, including the Arctic and large parts of the boreal forest zone, are experiencing much faster surface warming than the Earth as a whole (Lu and Cai, 2010; Screen et al., 2012). Atmospheric aerosol particles play an important and complex role in the high-latitude climate system. Firstly, large reductions in anthropogenic sulfur emissions in Europe and North America have decreased sulfate aerosol concentrations over high latitudes during the past three decades, thereby enhancing the warming observed over those areas (Shindell and Faluvegi, 2009). Secondly, black carbon aerosols in Arctic air and snow contribute to local warming and the resulting snow-albedo climate feedback mechanism during spring (Law and Stohl, 2007; Flanner et al., 2009). Thirdly, boreal forests themselves are a major source of biogenic secondary aerosol particles during the

Published by Copernicus Publications on behalf of the European Geosciences Union. 
extended summer season (Kulmala et al., 2011; Tunved et al., 2006a). These particles have been estimated to cause a significant cooling effect via their interaction with clouds (Spracklen et al., 2008; Lihavainen et al., 2009), and to be part of a potentially important negative feedback loop in a warming climate (Tunved et al., 2008; Kulmala et al., 2004a; Paasonen et al., 2013).

The cooling potential of secondary particles produced by boreal forests is closely connected with aerosol dynamical processes taking place during atmospheric transport, especially the particle growth, since secondary particles need to reach diameters larger than approximately $50-100 \mathrm{~nm}$ in order to participate in cloud droplet activation (Kerminen et al., 2005; Komppula et al., 2005; Sihto et al., 2011; Spracklen et al., 2011).

Long-term aerosol measurements conducted at various northern European sites have brought plenty of new insight into the formation and growth behavior of boreal forest aerosols (Kulmala et al., 2004b; Vehkamäki et al., 2004; Dal Maso et al., 2007; Svenningsson et al., 2008; Asmi et al., 2011). The problem with these studies, however, is that particle growth rates are obtained only from a subset of days with the most prominent growth, which is very likely to bias the results. Another problem with measurements conducted at fixed sites is that they provide limited amount of information on the mutual interaction between various aerosol dynamical processes during atmospheric transport. Finally, such measurements do not reveal the spatial extent of secondary aerosol formation, nor how long it takes to establish a balance between the aerosol formation and removal mechanisms.

One approach to investigating aerosol dynamics during atmospheric transport is to look for and analyze air mass transport situations between two measurement stations. In the boreal forest environment, aerosol dynamics during atmospheric transportation has been investigated in only a few studies. Komppula et al. (2006) concentrated on new particle formation (NPF) days in Finnish Lapland. They combined particle number size distribution measurements and simulations of aerosol dynamics, and showed that secondary particle formation from biogenic precursors often dominated over the particle sinks when the air masses traveled a distance of over $200 \mathrm{~km}$. Tunved et al. (2004) investigated the south-tonorth air mass transport from Aspvreten in southern Sweden to Värriö in northern Finland, whereas Tunved et al. (2006b) analyzed the transport in the opposite direction, from Finnish Lapland to Hyytiälä, which is located about $300 \mathrm{~km}$ north of Helsinki. According to these studies, there was a significant difference between the dynamics of the measured particle number size distributions in these two transport directions; when air masses were moving to the south, the number concentration of particles in the Aitken mode was seen to increase while the mode peak diameter of the number size distribution remained unaltered, whereas for the opposite direction the mode peak in the number size distribution was seen to move to larger sizes. Consequentially, although the total number concentration of particles decreased, the total mass concentration grew.

An alternative approach was introduced by Tunved et al. (2006a), who classified air mass trajectories arriving at Finnish rural stations based on their transport time over the boreal forest area. By combining a large set of such air masses based on trajectory analysis, Tunved et al. (2006a) were able to determine the "average" dynamical behavior of secondary particles formed in clean air transported from sea areas to forest areas. They found that the formation of new particles could be observed only after the air masses have traveled for a few hours above the boreal forest zone, and that the newly formed particles gradually grow in size during the atmospheric transport in response to biogenic emissions. The particle mass concentration was found to increase roughly linearly with the total estimated monoterpene emission into the moving air parcel, whereas the total particle number concentration appeared to saturate between about 1000 and $2000 \mathrm{~cm}^{-3}$ after a couple of days of air mass transport.

In this manuscript, we combine the two approaches discussed above for the measurement data obtained from three stations located within a distance of couple hundred $\mathrm{km}$ from each other at the northern edge of the boreal forest zone. We will focus our attention on the extended summer season (April to September), which is the time period with active biogenic aerosol formation and low regional anthropogenic primary particle emissions, yet we also briefly discuss the winter period. The principal goal of this paper is to get new insight into aerosol dynamical processes taking place in air masses transported over high northern latitudes. More specifically, we aim to address the following questions: (i) are there fundamental aerosol dynamical differences between air masses entering the different stations, or in air transported between the different station pairs?, (ii) does the west-to-east air mass transport differ from the east-to-west transport in any observable way?, (iii) how fast do particles effectively grow in size during air mass transport and how does this differ from the growth observed during nucleation events at fixed measurement sites?, and (iv) what is the net effect of aerosol source and sink processes on particle number concentrations during atmospheric transport? We hypothesize that aerosol formation and growth influence the boreal forest aerosol properties during the whole extended summer period, not just during the days with most active NPF, and that the net effect of these processes on the particle number size distribution is most pronounced in clean marine air masses entering the boreal forest region. 


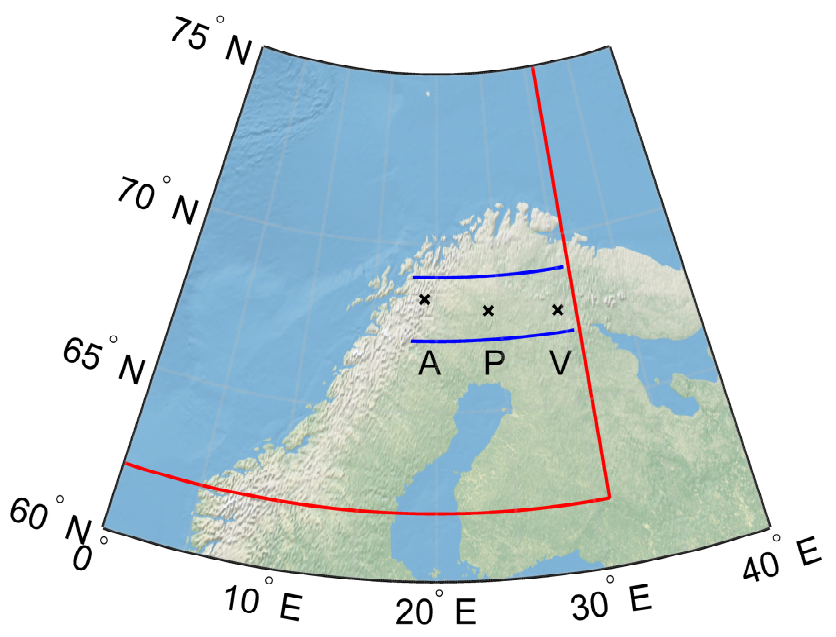

Fig. 1. A map of northern Scandinavia. The measurement stations are located approximately in a line from west to east in the following order: Abisko, Pallas, Värriö (A, P, and V in the map). Red lines show the sector from where the trajectories are accepted when studied the aerosol dynamics over the continent. Blue lines show the limits for the trajectory paths when studying aerosol dynamics between the measurement stations (Map: Natural Earth data).

\section{Materials and methods}

\subsection{Measurements}

\subsubsection{Site descriptions}

In this paper we compare aerosol number size distribution data from three rural stations. Two of them, Värriö and Pallas, are continuous particle measurement stations and located in Finland. The data set is completed with campaign data from Abisko, which is located in Sweden, near the Norwegian border. The measurement sites are located roughly in a line from west to east at latitude $67-68^{\circ} \mathrm{N}$ (see Fig. 1), and the distances from Abisko to Pallas, from Pallas to Värriö, and from Abisko to Värriö are approximately 230, 230, and $440 \mathrm{~km}$, respectively.

Abisko $\left(68.35^{\circ} \mathrm{N}, 19.05^{\circ} \mathrm{E}, 360 \mathrm{~m}\right.$ a.s.l.) (See Svenningsson et al., 2008): the measurements were made at Stordalen Mire, $14 \mathrm{~km}$ east from the Abisko research station. The mire is situated between Lake Torneträsk and the Kiruna-Narvik road and railway lines in a wide, east-west oriented valley. The surrounding landscape is dominated by a mix of subarctic mire, birch forest, and mountain tundra. The main chain of mountains, with several peaks above $1500 \mathrm{~m}$ a.s.l., is located west from the site, and further west is the coast of the Atlantic Ocean (at a distance of ca. $100 \mathrm{~km}$ from the station).

Pallas $\left(67.97^{\circ} \mathrm{N}, 24.12^{\circ} \mathrm{E}, 565 \mathrm{~m}\right.$ a.s.l.) (see Hatakka et al., 2003): the Sammaltunturi measurements site at the Pallas-Sodankylä GAW (Global Atmospheric Watch) station is situated on the top of a fell about $300 \mathrm{~m}$ above the surrounding area. The surroundings of the station are covered by mixed boreal forest with Scots pine, spruce and birch trees, whereas the site itself is located about $100 \mathrm{~m}$ above the timber line. There are no significant local or regional pollution sources close to the site.

Värriö $\left(67.77^{\circ} \mathrm{N}, 29.58^{\circ} \mathrm{E}, 390 \mathrm{~m}\right.$ a.s.l.) (see Hari et al., 1994): the SMEAR (Station for Measuring EcosystemAtmospheric Relations) I station in Värriö is situated on a hilltop and it is surrounded by an approximately $60 \mathrm{yr}$ old Scots pine forest. The Värriö research station is located about $1 \mathrm{~km}$ south from the measurement site. The altitude of the site, $390 \mathrm{~m}$ a.s.l., is slightly below the timber line of the area surrounding the station ( $400 \mathrm{~m}$ a.s.l). There are no local pollution sources close to the station. The distance to the nearest small road is $8 \mathrm{~km}$ and the distance to the nearest major road is $100 \mathrm{~km}$. The main anthropogenic pollution sources are the mining area in Kovdor, Russia and the nickel-copper smelters in Montchegorsk and Nikel, Russia, located $43 \mathrm{~km}$, $150 \mathrm{~km}$ and $190 \mathrm{~km}$, respectively, from the station.

\subsubsection{Instrumentation}

Data were collected between 1 August 2005 and 31 December 2008. The number size distribution measurements were performed using either a differential mobility particle sizer (DMPS) or a scanning mobility particle sizer (SMPS). Both instruments are based on particle mobility techniques, in which particles are charged and then classified according to their electrical mobility. The number density of several particle diameter bins is counted.

In Abisko, an SMPS was used with a custom-built Hauketype differential mobility analyzer (DMA) and TSI Model 3010 Condensation Particle Counter (CPC) (Svenningsson et al., 2008) was used. The size range of the instrument was $10-500 \mathrm{~nm}$ and the time resolution was $3-5 \mathrm{~min}$. The inlet was placed $3.4 \mathrm{~m} / 4.4 \mathrm{~m}$ above the surrounding mire.

In Pallas, the particle number size distribution data were measured using a DMPS with a Hauke-type DMA and TSI CPC Model 3010 (Komppula et al., 2003). The measurement range was $7-500 \mathrm{~nm}$, and the size range was scanned once in every $5.5 \mathrm{~min}$. The measurement inlet was $7 \mathrm{~m}$ above the ground (Komppula et al., 2005).

At the Värriö station, a DMPS with two Hauke-type DMAs and a TSI Model 3025 CPC (Ruuskanen et al., 2003; Dal Maso et al., 2005) was used. The size range of the measured particles was $3-850 \mathrm{~nm}$, and the time resolution was $10 \mathrm{~min}$. The inlet was located at a height about $2 \mathrm{~m}$ above ground level.

\subsection{Data analysis methods}

\subsubsection{New particle formation events}

We analyzed the particle number size distributions of each day and classified the days into event, non-event, and undefined days according to the schema introduced by Dal Maso 
et al. (2005) (see also Kulmala et al., 2012). On event days, a new growing sub-25 $\mathrm{nm}$ particle mode that lasted for at least an hour was observed, and at undefined days either a nongrowing new sub- $25 \mathrm{~nm}$ mode or a growing $>25 \mathrm{~nm}$ mode was seen. If there was neither a growing nor a sub- $25 \mathrm{~nm}$ mode, the day was classified as a non-event day. Furthermore, the event days were divided into classes Ia and Ib according to whether it was possible to calculate growth and formation rates of freshly nucleated particles. For the class Ia events, we fitted a sum of up to three lognormal distributions to the particle number size distribution data (Hussein et al., 2005) in order to get the geometric mean diameters of each mode. The growth and formation rates were calculated as in Dal Maso et al. (2005). The growth rate was obtained by fitting a line to the geometric mean diameters of the sub$25 \mathrm{~nm}$ modes during the formation burst, and the formation rate was calculated using the equation:

$J_{\text {nuc }}=\frac{\mathrm{d} N_{\text {nuc }}}{\mathrm{d} t}+F_{\text {coag }}+F_{\text {growth }}$,

where $\mathrm{d} N_{\text {nuc }} / \mathrm{d} t$ is the rate of change of nucleated particle concentration, $F_{\text {coag }}$ is the loss of particles by coagulation, and $F_{\text {growth }}$ is the rate of particles growing out of the size range. The lower detection limits of the DMPS or SMPS instruments varied between 3 and $10 \mathrm{~nm}$, which also affected the calculated rates.

\subsubsection{Aerosol dynamics over the continent}

Tunved et al. (2006a) showed that the total mass concentration of submicron aerosol particles in the background air over Scandinavia is linearly proportional to the time the corresponding air mass had spent over the continent. In this work, we repeated this analysis and extended it to include the Abisko station. We calculated and intercompared the median particle number size distributions for all stations as a function of the time the corresponding air masses had spent over the continent during the last $96 \mathrm{~h}$. In the air mass analysis, we used the trajectories calculated using the HYSPLIT (Hybrid Single Particle Lagrangian Integrated Trajectory) model (Draxler and Hess, 1998). We limited the area for the trajectories as shown in Fig. 1. The chosen area allowed the trajectories coming from the Atlantic Ocean and ending at Abisko to have a wide range of overland times. Trajectories needed to start over the Atlantic Ocean and spend $90 \%$ of their overland time inside the chosen sector. The starting altitude over the ocean was not limited, since air masses arriving above the boundary layer at marine environment were also assumed to also be clean enough. The total fractions of air mass trajectories that passed our requirements were $81 \%$ for Abisko, $75 \%$ for Pallas and $58 \%$ for Värriö. We calculated the results for the summer and winter periods separately.

We calculated the apparent growth rate and the increase rates of the particle number and mass concentration and condensation sink for all the three stations considered here. At each station, we calculated the hourly averages of particle number size distributions, and assigned those to the corresponding overland times calculated from the trajectories. For each of these particle number size distributions we quantified the particle diameter that had the maximum concentration (referred to as peak diameter). Peak diameters increased as a function of the overland time. To quantify this apparent growth, we first took all the peak diameters for each fixed overland hour bin, and calculated their geometric count median diameters (CMD). We used these CMD values for further analysis instead of the mean values, since for a fixed overland time, the peak diameters were log-normally distributed. Finally, we determined the apparent growth rate by fitting a line to these CMD values as a function of overland time. For statistical reasons, only those overland hour bins with more than 10 number size distributions were taken into account when fitting the lines.

Similar steps to those described above were carried out to calculate the mass accumulation rate and the condensation sink (Dal Maso et al., 2002) increase rate as a function of the overland time. When calculating the apparent growth, our initial values were the peak diameters, but now we used the mass concentrations or condensation sink values calculated from the particle number size distributions. The count mean diameter values of both the mass concentrations and condensation sink values were calculated for each overland hour bin, and a line was fitted along the results. The average density of the aerosol particles was assumed to be $1.5 \mathrm{~g} \mathrm{~cm}^{-3}$ (as in Tunved et al., 2006a). We concentrated our study on the largest common range of particle diameters that was measured at each of the stations, namely sizes between 10 and $450 \mathrm{~nm}$, to make the results intercomparable.

\subsubsection{Aerosol transport between stations}

Particle number size distribution data from several measurement stations combined with the calculated air mass trajectory information allowed us to regionally study the dynamical changes of aerosol particle populations. For this, we focused on the air masses that had traveled over two stations, and then compared the aerosol properties between the different station pairs. Each station pair had an upwind and a downwind station.

The aerosol dynamical processes are dependent on the shapes of the particle number size distributions, and thus when studying the evolution of aerosol populations, the initial states need to be comparable. After we had selected the trajectories that passed a pair of measurement stations, we clustered the particle number size distributions measured at the upwind station to obtain a set of different initial states.

Clustering the particle number size distributions was conducted as follows. The $k$ means clustering algorithm from Matlab Optimization toolbox (MathWorks Inc., 2011) was used for the task. The algorithm groups the data into $k$ clusters so that the measure between each cluster's center and its 
members are minimized. In other words, our aim was try to reduce the complexity of the data sets by finding data subsets that were internally similar to each other - in our case, groups of similar particle number size distributions. Measured particle number size distributions were mapped into the size bins $\mathrm{d} N / \mathrm{d} \log D_{p}$, where $\mathrm{d} N$ is the particle number concentration in each size bin and $\operatorname{d} \log D_{p}$ is logarithm of the width of the size bin. Next we calculated the squared Euclidian measure between two number size distributions. The $k$ means method with squared Euclidian measure as a measure has been shown to work best when comparing several clustering algorithms for particle number size distributions (Beddows et al., 2009). However, our method differed from the normalization by Beddows et al. (2009), who normalized the vector lengths. We did not do this, since we were also interested in the aerosol loading, not only the shapes of the particle number size distributions.

One should note that the basis vectors used in our clustering algorithm were chosen in a practical rather than a mathematical way; consequentially, the basis vectors are not a normalized Euclidean basis set even though we used Euclidean measure. Our aim was to divide the particle number size distributions into separate groups, and the results showed that our method is suited for that.

The selection of the clusters was a two-phase process. First we determined the best total number of clusters. We performed the clustering algorithm with different fixed numbers of clusters, and chose the best number based on the mean of the so-called silhouette values (MathWorks Inc., 2011). The silhouette values show how tightly the data points are associated with their assigned clusters and how dissimilar they are from other clusters. The number of clusters that produced the highest silhouette value was chosen. The second phase was to ignore those clusters that had only a low number of size distributions.

Typically, the first phase resulted in 3-6 clusters per site. Of these, clusters with fewer than 30 number size distributions were disregarded (because of the low generalization) in the second phase. Each of the studied clusters was linked to a set of particle number size distributions at the downwind station via the trajectories. The statistical number size distributions (mean, and 16th and 83th percentiles) for each cluster were calculated and plotted at both the upwind and the downwind station. Furthermore, we fitted a sum of lognormal distributions to the mean number size distributions and analyzed the dynamics of the particle modes.

The trajectory selection was carried out as well. We chose the trajectories that passed several measurement sites in the following way. First, the 96h HYSPLIT backward trajectories that arrived at each station were calculated once per hour, each with a backward time resolution of one hour. We increased the resolution of each trajectory to ten minutes by interpolating the paths. We defined an arriving trajectory as having passed another site if it had gone through a circle with a radius of $25 \mathrm{~km}$ centered at the other site. The length of the
Table 1. Fraction of NPF event days compared to all analyzed days with data (Ev/A) or to days which are classified either to event or non-event days $(\mathrm{Ev} / \mathrm{Cl})$. Data from Abisko was from campaigns (most data from the winters 2005-2006 and 2006-2007 are missing), and it thus cannot be compared to the values for Pallas and Värriö.

\begin{tabular}{lcc}
\hline & Ev/A (\%) & Ev/Cl (\%) \\
\hline Abisko & 24 & 30 \\
Pallas & 19 & 23 \\
Värriö & 15 & 21 \\
\hline
\end{tabular}

radius was based on the uncertainty of the trajectories, which can be of order of $10-30 \%$ of the distance the proceeding trajectory (Stohl, 1998). For example, this means that when the distance from Pallas to Värriö or from Abisko to Pallas is about $200 \mathrm{~km}$, the location error can be tens of kilometers. We decreased the effects of different land use by restricting the trajectory paths to be between the latitudes of $67.1-69.0^{\circ} \mathrm{N}$. The area inside this corridor is mostly very sparsely populated. The centers of population include the towns Sodankylä and Kiruna. We did a sensitivity check on the Kiruna mining town by estimating whether it had any influence on measured aerosol populations when air masses were traveling between Abisko and Pallas.

\section{Results and discussion}

Our data set covered the measured particle number size distributions at the three stations between August 2005 and December 2008. The gaps in the data set limit the intercomparison of the NPF analysis (Fig. 2). The most complete data set originated from Värriö, and the largest number of gaps was in the Abisko data set (which was derived during a number of shorter measurement campaigns). The fractions of days without data during the whole time period were $52 \%, 13 \%$, and $6 \%$ for Abisko, Pallas and Värriö, respectively. Simultaneous data from all the three measurement sites were more frequent for summer and autumn compared to the other two seasons. Since there were no data from most of the winter days at Abisko, the fraction of the event days compared to all analyzed (Ev/A) or classified (either event or non-event) $(\mathrm{Ev} / \mathrm{Cl})$ days in Abisko cannot be directly compared to those at Pallas or Värriö. When comparing Pallas and Värriö, we found that there was a slightly higher fraction of event days at Pallas (Fig. 3 and Table 1).

When comparing our results to studies containing longer time series, the overall differences were quite small and probably within normal interannual variation. In a study containing $7 \mathrm{yr}$ from Värriö and $5 \mathrm{yr}$ from Pallas (Dal Maso et al., 2007), both Ev/A and $\mathrm{Ev} / \mathrm{Cl}$ fractions were very similar to ours in Pallas and slightly higher in Värriö (19\% EV/A or $27 \% \mathrm{Ev} / \mathrm{Cl}$ ). In a $5 \mathrm{yr}$ study of Värriö, Vehkamäki et 


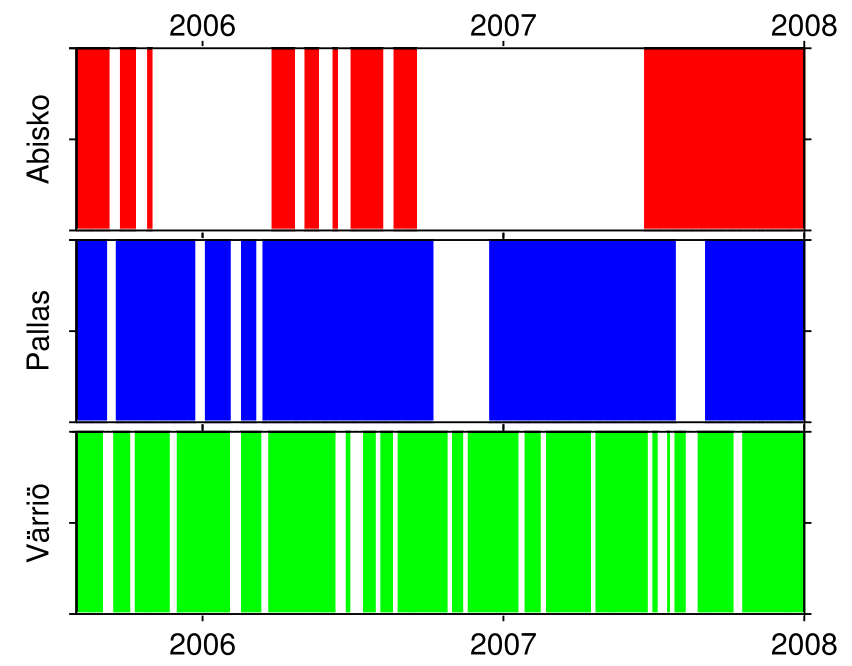

Fig. 2. Colored areas show the time intervals when particle number size distribution data is available from corresponding stations.

al. (2004) found lower fractions (monthly Ev/A varied between 3 and more than $20 \%$ ), but applied a slightly different classification from ours, which might cause some differences. In an $11 \mathrm{yr}$ study of Pallas, the value of Ev/A varied between 6 and $27 \%$ during different months (Asmi et al., 2011).

The particle formation rates were calculated at 3.7, and $10 \mathrm{~nm}$ for Värriö, Pallas, and Abisko, respectively; these are the lowest measurable particle diameters at these three sites. By doing this calculation, our results can be compared with previous studies conducted at the same sites (Table 2). The mean formation rates were almost equal at all the sites $\left(0.1 \mathrm{~cm}^{-3} \mathrm{~s}^{-1}\right)$ and confirm previously published results (Vehkamäki et al., 2004; Dal Maso et al., 2007; Asmi et al., 2011). The mean growth rate of particles during the NPF events in Abisko exceeded the growth rates in Pallas and Värriö.

\subsection{Evolution of the particle properties over the continent}

It has been shown for both Pallas and Värriö that, on average, the particle size and the accumulated particle mass concentration grow as a function of the time that the corresponding air mass has spent over the land (Asmi et al., 2011; Tunved et al., 2006b). We extended this analysis to include Abisko and the winter period.

\subsubsection{Summer period}

During the summer, air masses originating from the sea and arriving at the continental areas were assumed to be relatively free of anthropogenic influence. Observed particle number size distributions (Fig. 4) and low total particle number concentrations (Fig. 5c) associated with short overland transport

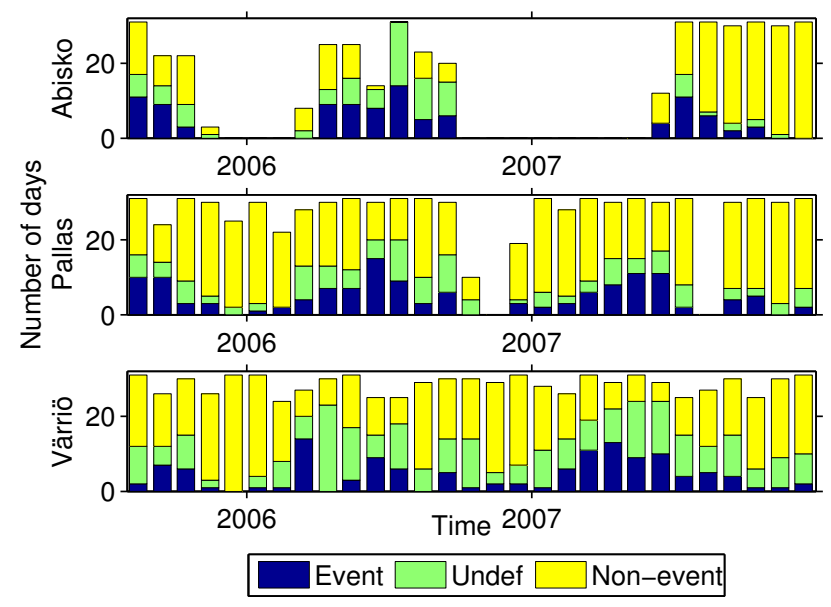

Fig. 3. Number of NPF event days, non-NPF event days, and undefined days in all measurement sites.

times support this assumption. With short overland times, the particle number size distribution in all stations had a bi-modal structure with mode peaks at $30-40 \mathrm{~nm}$ and 130 $170 \mathrm{~nm}$ in diameter. This finding fits well with measured marine particle number size distributions (Covert et al., 1996; Koponen et al., 2002; Heintzenberg et al., 2004; O’Dowd et al., 2004).

When the air mass traveled over the land, the formation and growth of aerosol particles could be observed as increases in particle number concentrations and mean diameters of the Aitken mode. The particle number concentrations increased at rates of about $0.01 \mathrm{~cm}^{-3} \mathrm{~s}^{-1}$ until the overland times of around $30-40 \mathrm{~h}$ and thereafter at rates between about 0.001 and $0.002 \mathrm{~cm}^{-3} \mathrm{~s}^{-1}$ (Fig. 5c). Eventually, the total particle number concentration saturated towards levels of $900-1100 \mathrm{~cm}^{-3}$. This feature indicates that by overland transport times of about $30-40 \mathrm{~h}$, the formation of new particles as the main process had been overtaken either by vapors condensing or by small clusters coagulating onto the larger particles. The slow increase in particle number concentrations - even at long overland transport times - might also be connected to primary particle emissions.

In contrast to the particle number concentration, the particle mode diameter, accumulated mass concentration and condensation sink all increased during the entire $96 \mathrm{~h}$ time period (Fig. 5a, b, d). The condensation sink values corresponding to the $30-40 \mathrm{~h}$ overland time were between $0.8 \times 10^{-3} \mathrm{~s}^{-1}$ and $1.2 \times 10^{-3} \mathrm{~s}^{-1}$.

The median particle number size distributions were found to have similar structures at all the stations. For overland times less than $40-50 \mathrm{~h}$, the number size distributions were bimodal. The mode with the smaller particle diameter started at around $20-30 \mathrm{~nm}$ and grew as a function of time, whereas the second mode, with particle diameters of around 100-200 nm, remained more stationary. When comparing the 
Table 2. Statistics of the properties of NPF events. Calculated means, medians and standard deviations, as well as 10th and 90th percentiles (P10-P90). Here, too, the shorter measurement periods in Abisko prevent direct comparison (see Table 1). Due to different cut-off sizes of the instruments, the formation rates are $J_{10}, J_{7}$ and $J_{3}$, for Abisko, Pallas, and Värriö, respectively.

\begin{tabular}{lccc|ccr}
\hline & \multicolumn{3}{c|}{ Growth rate GR $\left(\mathrm{nm} \mathrm{h}^{-1}\right)$} & \multicolumn{3}{c}{ Formation rate $J\left(\mathrm{~cm}^{-3} \mathrm{~s}^{-1}\right)$} \\
\cline { 2 - 7 } & Mean \pm Std & Median & P10-P90 & Mean \pm Std & Median & P10-P90 \\
\hline Abisko & $3.7 \pm 2.7$ & 3.0 & $1.1-6.6$ & $0.1 \pm 0.2$ & 0.05 & $0.002-0.3$ \\
Pallas & $3.3 \pm 2.3$ & 2.6 & $1.3-6.6$ & $0.1 \pm 0.2$ & 0.08 & $0.01-0.3$ \\
Värriö & $2.8 \pm 2.0$ & 2.0 & $1.0-6.2$ & $0.09 \pm 0.08$ & 0.07 & $0.02-0.2$ \\
\hline
\end{tabular}
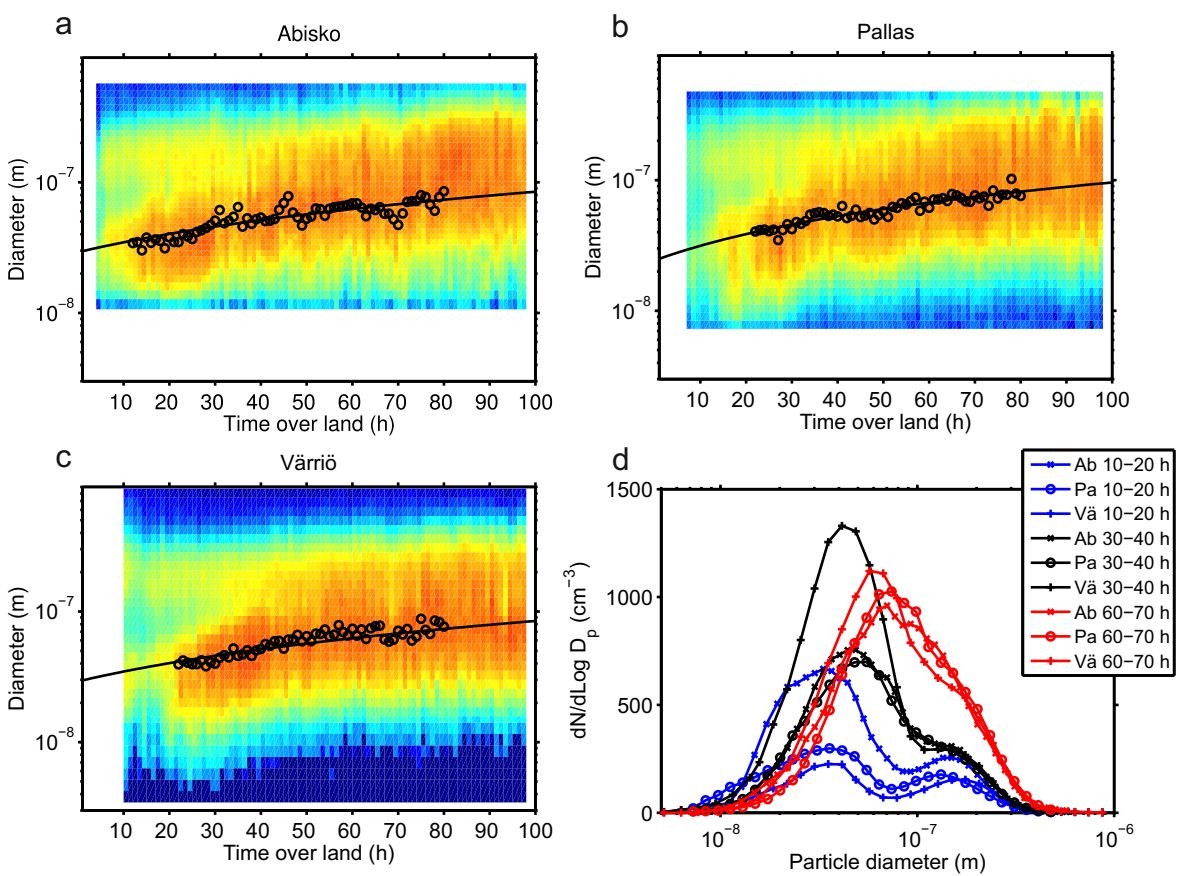

Fig. 4. (a-c) Median number size distributions as a function of time the corresponding air mass has spent over land during the last $96 \mathrm{~h}$. Only summer period (1.4-30.9) covered. (d) Mean number size distributions for certain time periods for all stations.

average particle number size distributions for $10-20 \mathrm{~h}$ overland times (blue lines in Fig. 4d), we can see that the shapes of the number size distributions were quite similar for all of the stations, with Abisko having the highest number concentration of Aitken-mode particles. For overland times of 30-40 h (black lines in Fig. 4d), Abisko and Pallas continued to have similar number size distributions, and Värriö clearly had the highest Aitken-mode particle number concentrations. For overland times of $60-70 \mathrm{~h}$, the number size distributions (red lines in Fig. 4d) at all stations were relatively similar and the original bi-modality had in practice disappeared.

In order to compare the growth of the particles, we calculated the apparent increase rates with error limits for the mode peak diameter, mass accumulation and condensation sink using the method explained in Sect. 2.2.2 (Table 3). One should note that the error limits were based on a mathematical line fitting, which omits the physical uncertainty in the measurements, the inaccuracy of the method itself and the pre-assumptions made for the data (e.g. which time interval was used when calculating the rates), which are complicated to access. Thus the reported errors should be considered lower-limit estimates for the errors.

The apparent particle growth rates when air masses were passing over the land were relatively similar for all the stations, with average values between 0.55 and $0.72 \mathrm{~nm} \mathrm{~h}^{-1}$ (Table 3) These growth rates are lower (by factors of 3-6) than the "real" particle growth rates observed during NPF event days (see Table 2). We think that the main reason for this difference is that the "real" particle growth can be determined for new particle event days only when particles tend to grow faster than during the non-event days included in determining the "apparent" particle growth rate. Furthermore, the "apparent" particle growth rate may be affected not only by particle growth but also by other processes, such as size-dependent particle removal rate and primary particle emissions. To ensure that the apparent particle growth was caused not only by 

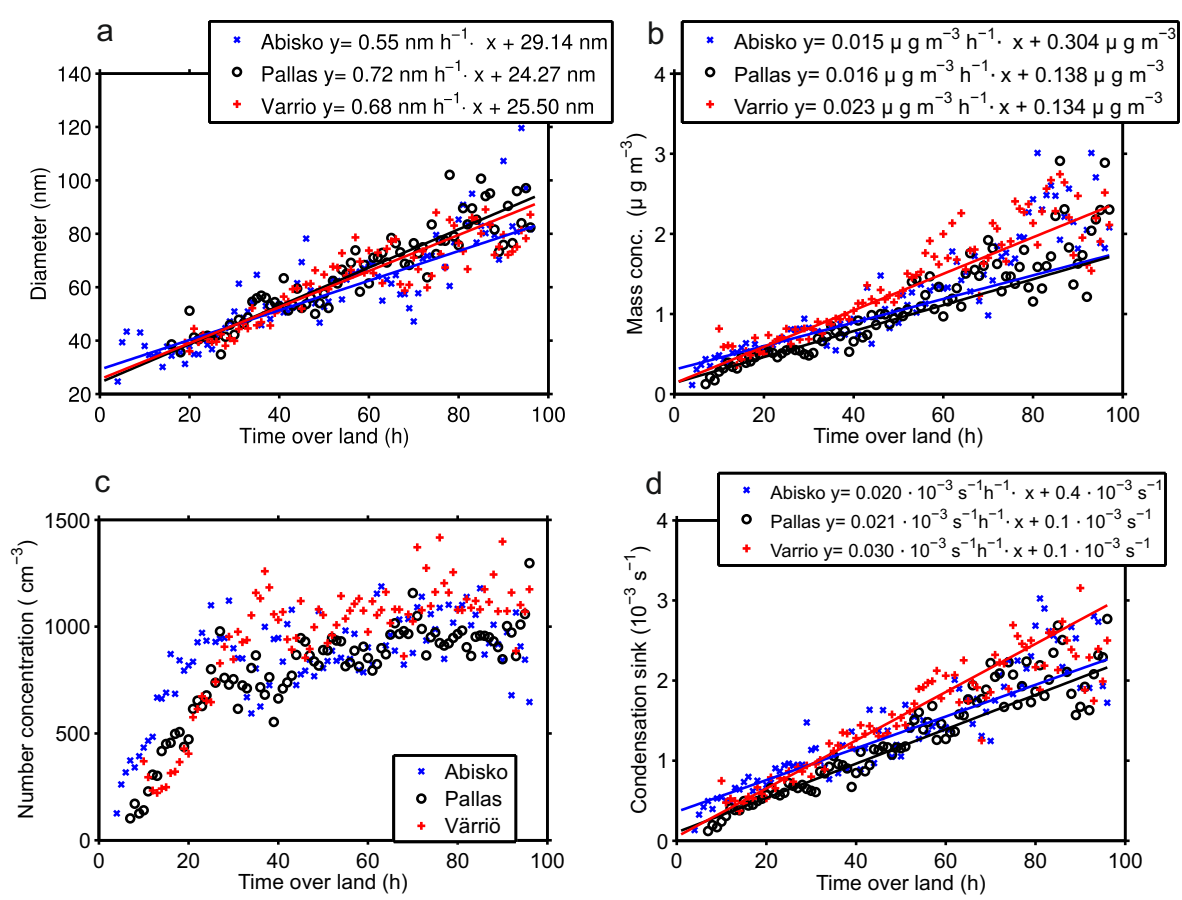

Fig. 5. Particle mode diameter (a), integrated mass concentration (b), number concentration (c), and condensation sink (d) as a function of time the corresponding air mass has spent over land.

Table 3. Increase rates of mode peak diameter, accumulated mass concentration, and condensation sink when air masses travel over land. Summer period (1.4-30.9) covered. See Fig. 5.

\begin{tabular}{lrrr}
\hline & Abisko & Pallas & Värriö \\
\hline Apparent particle growth rate $\left(\mathrm{nm} \mathrm{h}^{-1}\right)$ & $0.55 \pm 0.04$ & $0.72 \pm 0.04$ & $0.68 \pm 0.05$ \\
Over-land-times used (h) & $12-80$ & $22-80$ & $22-80$ \\
Accumulated mass conc. increase $\left(\mu \mathrm{gm}^{-3} \mathrm{~h}^{-1}\right)$ & $0.015 \pm 0.002$ & $0.016 \pm 0.001$ & $0.023 \pm 0.001$ \\
Over-land-times used (h) & $5-50$ & $10-50$ & $12-50$ \\
Apparent growth of condensation sink $\left(\mathrm{s}^{-1} \mathrm{~h}^{-1}\right)$ & $0.022 \pm 0.001$ & $0.026 \pm 0.001$ & $0.029 \pm 0.001$ \\
Over-land-times used (h) & $5-80$ & $10-80$ & $10-80$ \\
\hline
\end{tabular}

averaging the NPF events over all days, we calculated a separate apparent growth rate using data from the non-event days only. In the result, no significant difference from the all-data results was seen.

In Tunved et al. (2006a), the average integrated observed particle mass for Pallas and Värriö was calculated to in-

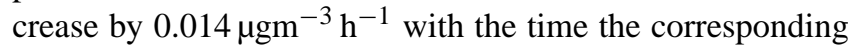
air mass had spent over the continent. In our analysis we obtained similar values despite the different data sets used. The integrated particle mass concentration increase rates in our study were between 0.015 and $0.023 \mu \mathrm{g} \mathrm{m}^{-3} \mathrm{~h}^{-1}$ for the stations. The overland times used here to calculate the slopes were chosen to be below $50 \mathrm{~h}$ because the residuals of the linear fit were smaller for such a time window than if the upper limit had been chosen to be $80 \mathrm{~h}$. In the latter case, slightly larger (between 0.020 and $0.027 \mu \mathrm{g} \mathrm{m}^{-3} \mathrm{~h}^{-1}$ ) slopes were obtained, but the fitting was worse, especially for Abisko.
These features may be caused by the lower number of data points for the larger overland transport times, yet we cannot exclude the influences of real aerosol dynamic processes, either. The condensation sink was found to increase linearly with increasing overland transport times at all the stations. The corresponding increase rates were between 0.020 and $0.030 \mathrm{~s}^{-1} \mathrm{~h}^{-1}$. Värriö had the highest value in line with the other variables: Värriö had also the highest apparent growth rate, mass accumulation rate and particle number concentration after its saturation.

When looking at the apparent particle growth rate and accumulated particle mass increase, we found some differences between the stations. Both of these values were the lowest for Abisko. However, the differences between the values were not large, and particularly the accumulated mass increase rates for Pallas and Abisko were close to each other. 

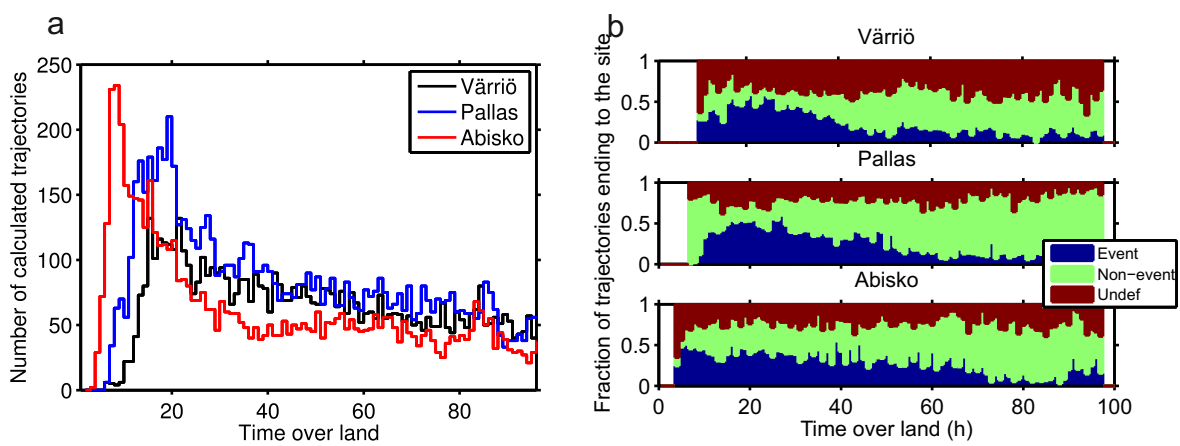

Fig. 6. (a) Distribution of the times the trajectories spent over land. (b) Fractions of the trajectories that ended at each site during event, non-event, or undefined days.

The histogram of the times that the trajectories had spent over land peaked at $8 \mathrm{~h}$ for Abisko and at around $20 \mathrm{~h}$ for Pallas and Värriö (Fig. 6a), reflecting the relative distances of these stations from the ocean and the prevailing westerly winds. For Pallas and Värriö, the trajectories corresponding to NPF event days peaked at around 20-25 h (slightly earlier in Pallas than in Värriö) of the overland transport time. (Fig. 6b). This supports the principal idea that particle nucleation occurs easier in fresh air coming from the ocean, while the transport time need to be sufficient for enough condensable gases to be formed. However, in Abisko a frequent occurrence of NPF was already observed soon after the air masses had arrived at over the land. The reason for the observed differences between Abisko compared with Pallas and Värriö cannot be explained by the differences in the values of the condensation sink (Fig. 5d). Moreover, for the extended summer season (April to September during 20052007), there was no significant difference between the stations' climatology (Fig. 7). Therefore, the reason for the earlier onset of nucleation in Abisko must be due to some other factors. Compared with Pallas and Värriö, Abisko has very distinct geographical features as it is located on the lee side of the Scandinavian Mountains and thus affected by air descending from over the mountain range, whereas Pallas and Värriö are both located on top of a hill. The Scandinavian Mountains very often generate (Jiang et al., 2004; Schroeder et al., 2009) standing atmospheric gravity waves (Nappo, 2002; Scorer, 1949) on their lee side. We speculate that on average, the air measured in Abisko is constrained into a shallower boundary layer that the air measured in either Pallas or Värriö, allowing more efficient accumulation of condensable vapors originating from biogenic emissions over Abisko. This would be the only major difference between the stations we could find that might be able to increase the probability of nucleation already at an earlier stage (Fig. 7). The faster nucleation onset in Abisko was also seen from the median particle number size distributions (Fig. $4 \mathrm{a}-\mathrm{c}$ ): the time when particle number concentrations in the Aitken mode in- creased significantly was around $7 \mathrm{~h}$ for Abisko, $15 \mathrm{~h}$ for Pallas and $20 \mathrm{~h}$ for Värriö.

One should note that even though the average climate was fairly similar, the average meteorological conditions related to the short overland times were different between the stations: for the same overland times, the longer distance from the ocean to Pallas or Värriö than to Abisko indicates higher wind speeds, which are likely connected to a lower pressure and thus different rain and radiation profiles. This in turn affects the event-day probability.

\subsubsection{Winter period}

Over northern Scandinavia, natural sources of primary particles and particle precursor vapors are expected to be much lower during the winter period (from the beginning of October to the end of March) compared with the summer period. By contrast, due to heating and combustion, primary emissions of man-made particles should be at their highest during the winter period (Karvosenoja et al., 2010; Lamberg et al., 2011).

We calculated the median particle number size distributions as a function of overland time for the winter period. Due to the low apparent growth of the Aitken-mode particles, the particle number size distribution remained bimodal even for long overland transport times (Fig. 8a). We also observed that when particles traveled over the continent, the mean modal diameters, particle number and mass concentrations all increased with increasing overland transport times (Fig. 8b-d). All these increase rates were, however, lower than during the summer time. The apparent growth of sub$80 \mathrm{~nm}$ particles was visible during the first $40 \mathrm{~h}$ of the overland transport time, after which the modal mean diameters saturated to values of around $50-70 \mathrm{~nm}$.

The highest mass accumulation rate during the winter period was observed at Abisko $\left(0.012 \pm 0.001 \mu \mathrm{g} \mathrm{m}^{-3} \mathrm{~h}^{-1}\right)$, and the corresponding rates were slightly lower $\left(0.007 \pm 0.001\right.$ and $\left.0.008 \pm 0.001 \mu \mathrm{g} \mathrm{m}^{-3} \mathrm{~h}^{-1}\right)$ in Pallas and Värriö, respectively (Fig. 8c). Abisko displayed also the highest particle number concentrations (Fig. 8d). The 


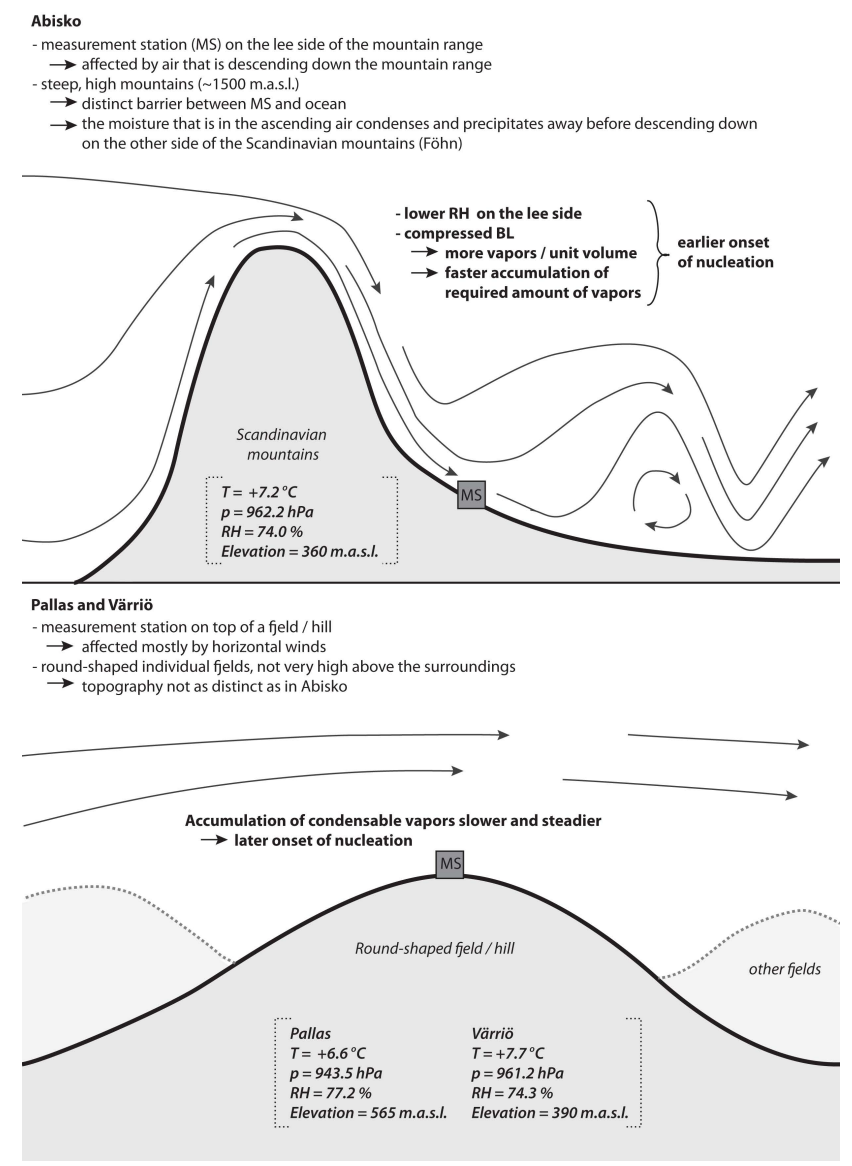

Fig. 7. General topographical and meteorological differences between the Abisko station and the Pallas and Värriö stations, and their effect on the onset of nucleation. Mean temperature, pressure and relative humidity are shown for the years 2005-2007 over the period 1.4.-30.9 for each station.

average increase rates of particle number concentrations as function of the overland transport time were of the order of $0.003 \mathrm{~cm}^{-3} \mathrm{~s}^{-1}$ for Abisko and $0.001 \mathrm{~cm}^{-3} \mathrm{~s}^{-1}$ for both Pallas and Värriö. Interestingly, these rates are of similar magnitude as those observed during the summer period at longer $(>30 \mathrm{~h}$ ) overland transport times.

\subsection{Aerosol dynamics between measurement stations}

Three measurement sites located in a row (with a total distance of $440 \mathrm{~km}$ ) offered the possibility of examining the dynamical properties of aerosols when they are transported by air masses between the sites. In order to do such an investigation, particle number size distributions at the upwind station need to be known. To standardize the starting situations, we first clustered the number size distributions at the upwind station separately for both summer and winter seasons, and then the changes of each of these clusters were analyzed.

The changes of the particle number size distributions of each cluster at the upwind and downwind stations show the average evolution during the transport (Figs. 9 and 10). We fitted a sum of lognormal distributions to the mean number size distributions of both stations in each pair to identify the changes in aerosol modes. The resulting peak diameters of these modes and their changes, as well as the mode concentrations and their changes, are listed for summer and winter periods in Tables 4 and 5, respectively. Since our aim was to use clusters as representative for general patterns rather than just single cases, all clusters with less than 30 number size distribution elements at both ends were discarded. Next we will analyze both air mass transport directions and all the station pairs along these transport routes. For each site pair, and for both seasons separately, we call the clusters with the highest number of distribution pairs "the most frequent cluster", and the cluster with the next highest number of the distribution pairs as "the second-most frequent cluster".

\subsubsection{Abisko-Pallas}

When clustering the particle number size distributions at Abisko, as related to air masses in the direction towards Pallas, the clustering with the highest silhouette value was obtained with five clusters for the summer period and with three clusters for the winter period. During the summer, two of these clusters had more than 30 elements, whereas during winter only one cluster had enough elements.

In both seasons, the most frequent cluster at Abisko had a bimodal structure with almost the same mode peak diameters, but in summer the particle number concentration of the Aitken mode was almost twice as high as it was during winter. In both seasons, the Aitken-mode particle number concentrations of these most frequent clusters increased during the air mass transport, whereas the accumulation-mode number concentration remained roughly unaltered. For the most frequent cluster of the summer period, the peak diameter of the Aitken mode shifted on average from $29 \mathrm{~nm}$ to $48 \mathrm{~nm}$ in $15 \mathrm{~h}$, corresponding to the growth rate of $1.3 \mathrm{~nm} \mathrm{~h}^{-1}$, whereas during the winter period, practically no shift was seen. The absence of changes during winter compared to the pronounced shift in the particle number size distribution during the growing season is most likely connected to the condensation of organic compounds formed from soil and vegetation emissions. The concentrations of the combined nucleation and Aitken-mode particles of the most frequent cluster increased with a rate of $0.01 \mathrm{~cm}^{-3} \mathrm{~s}^{-1}$ during the summer, and the corresponding increase during the winter was around one third of this value. In both seasons, the accumulation mode of the most frequent cluster had a larger mode peak diameter, but smaller concentrations in Pallas than in Abisko.

In summer at Abisko, the most dominant mode of the second-most frequent cluster was the accumulation mode, with a peak diameter of $148 \mathrm{~nm}$. After arriving at Pallas, this mode peaked at about the same size as it did in Abisko, and 

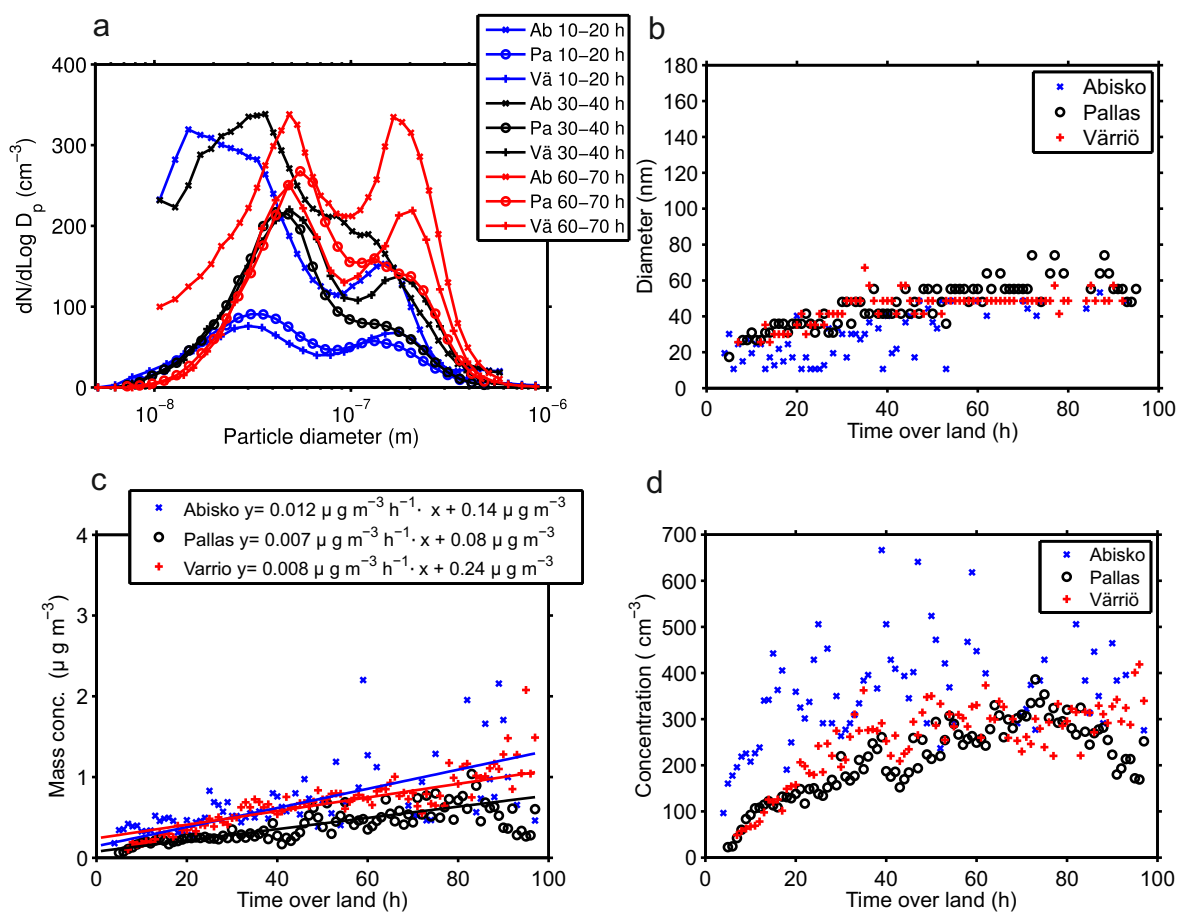

d

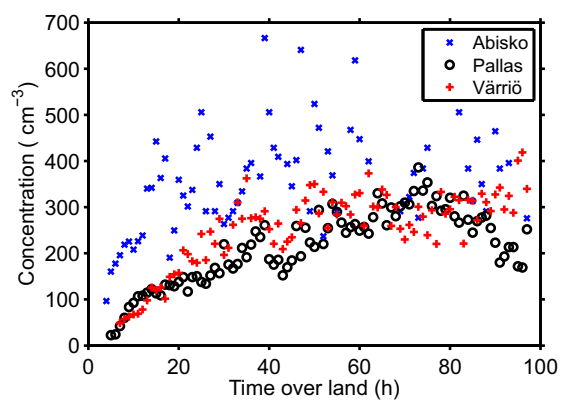

Fig. 8. (a) Mean particle number size distributions for certain overland time periods for all stations. Particle mode diameter (b), integrated mass concentration (c), number concentration (d) as a function of time the corresponding air mass has spent over land. In all subplots, only the winter period (1.10-31.3) is covered.

the particle concentration of that mode had increased slightly with a rate of $0.004 \mathrm{~cm}^{-3} \mathrm{~s}^{-1}$.

\subsubsection{Pallas-Värriö}

Particle number size distributions observed at Pallas, when considering trajectories in the direction to Värriö, clustered best to four sets in the summer and to three sets in the winter season, of which two in both cases had enough members for a further analysis. For the most frequent cluster during the summer, the Aitken mode shifted towards larger particles $\left(0.6 \mathrm{~nm} \mathrm{~h}^{-1}\right)$ and its concentration increased $\left(0.02 \mathrm{~cm}^{-3} \mathrm{~s}^{-1}\right)$. In winter, the mode peak diameter of Aitken-mode particles of the most frequent cluster shifted with a high rate of $2.1 \mathrm{~nm} \mathrm{~h}^{-1}$, but the concentration increase was low with a rate of $0.004 \mathrm{~cm}^{-3} \mathrm{~s}^{-1}$. In summer, the accumulation mode of this cluster shifted rapidly towards larger particles $\left(3.3 \mathrm{~nm} \mathrm{~h}^{-1}\right)$ and its concentration increased slightly $\left(0.004 \mathrm{~cm}^{-3} \mathrm{~s}^{-1}\right)$. During wintertime, the accumulation mode was already very weak in Pallas and did not change much. In summer, the general modal dynamics was quite similar to that associated with the Abisko-Pallas transport route.

In both seasons, the accumulation mode dominated the second-most frequent cluster at Pallas and the Aitken mode was also present. During the summer period, the number concentration of the accumulation mode of the second-most frequent cluster decreased and that of the Aitken mode increased, but the peak diameters of both modes remained unchanged. During the winter period, the peak diameters of both modes of the second-most frequent cluster increased rapidly $\left(1.7 \mathrm{~nm} \mathrm{~h}^{-1}\right.$ for the Aitken mode and $2.7 \mathrm{~nm} \mathrm{~h}^{-1}$ for the accumulation mode), and the concentration of accumulation mode also increased slightly.

\subsubsection{Pallas-Abisko}

The Pallas-Abisko air transport route had the least number of paired number size distributions and the only one cluster for summer period had enough members to fulfill the selection criteria of over 30 data pairs. As a result, the conclusions from this analysis are not as firm as those from the analysis of the other transport routes.

The number size distribution at Pallas for the one cluster had a low total concentration and trimodal structure with mode peak diameters of $22 \mathrm{~nm}, 63 \mathrm{~nm}$, and $169 \mathrm{~nm}$. On average, these peak diameters remained relatively unchanged when the air masses traveled to Abisko, and the total concentrations on all size ranges increased. For all the modes, particle number concentrations increased at a rate of $0.002 \mathrm{~cm}^{-3} \mathrm{~s}^{-1}$. No single process could explain this kind of observation, so it is likely that multiple processes together caused such an average change. 
Table 4. Dynamics of particle number size distributions when air masses travel from one site to another, summer season. The initial number size distributions are clustered and a log-normal fitting in the both ends of the paths is used to find the mode peak diameters and mode concentrations. In this table, the changes in mode peak diameters and mode concentrations are shown.

\begin{tabular}{|c|c|c|c|c|c|c|c|c|}
\hline & \multirow[t]{2}{*}{ Mean $\Delta t$} & \multirow[t]{2}{*}{ Mean RH } & \multicolumn{2}{|c|}{ Mode peak (nm) } & \multirow[t]{2}{*}{$\begin{array}{l}\text { Shift of } \\
\text { mode } \\
\left(\mathrm{nm} \mathrm{h}^{-1}\right)\end{array}$} & \multicolumn{2}{|c|}{$\begin{array}{c}\text { Concentration } \\
\text { of mode } \\
\left(\mathrm{cm}^{-3}\right)\end{array}$} & \multirow[t]{2}{*}{$\begin{array}{c}\text { Concentration } \\
\text { change } \\
\left(\mathrm{cm}^{-3} \mathrm{~s}^{-1}\right)\end{array}$} \\
\hline & & & Abisko & Pallas & & Abisko & Pallas & \\
\hline \multirow[t]{3}{*}{ Cluster 1} & $15 \mathrm{~h}$ & $77 \%$ & & 22 & & & 429 & $\mathrm{I}+\mathrm{II}$ both \\
\hline & & & 29 & 48 & 1.3 & 238 & 415 & +0.01 \\
\hline & & & 139 & 158 & 1.3 & 89 & 79 & -0.001 \\
\hline \multirow{4}{*}{ Cluster 2} & $13 \mathrm{~h}$ & $77 \%$ & & 16 & & & 70 & \\
\hline & & & 60 & 37 & & 270 & 196 & -0.001 \\
\hline & & & 148 & 151 & 0.2 & 748 & 954 & +0.004 \\
\hline & & & Pallas & Värriö & & Pallas & Värriö & \\
\hline \multirow[t]{2}{*}{ Cluster 1} & $16 \mathrm{~h}$ & $72 \%$ & 26 & 36 & 0.6 & 139 & 1051 & +0.02 \\
\hline & & & 110 & 163 & 3.3 & 318 & 92 & -0.004 \\
\hline \multirow[t]{3}{*}{ Cluster 2} & $28 \mathrm{~h}$ & $78 \%$ & 57 & 57 & 0.0 & 140 & 543 & -0.004 \\
\hline & & & 165 & 169 & 0.1 & 1206 & 667 & -0.005 \\
\hline & & & Pallas & Abisko & & Pallas & Abisko & \\
\hline \multirow[t]{4}{*}{ Cluster 1} & $22 \mathrm{~h}$ & $85 \%$ & 22 & 25 & & 45 & 199 & +0.002 \\
\hline & & & 63 & 62 & -0.0 & 122 & 250 & +0.002 \\
\hline & & & 169 & 197 & 0.5 & 103 & 237 & +0.002 \\
\hline & & & Värriö & Pallas & & Värriö & Pallas & \\
\hline \multirow[t]{3}{*}{ Cluster 1} & $17 \mathrm{~h}$ & $8 \%$ & 22 & & +1.5 & 78 & & $\mathrm{I}+\mathrm{II}$ both \\
\hline & & & 53 & 48 & -0.3 & 210 & 307 & +0.000 \\
\hline & & & 193 & 166 & -1.5 & 196 & 164 & -0.000 \\
\hline \multirow[t]{3}{*}{ Cluster 2} & $27 \mathrm{~h}$ & $81 \%$ & 22 & 28 & & 57 & 61 & \\
\hline & & & 97 & 98 & +0.0 & 808 & 612 & II+III both \\
\hline & & & 206 & 235 & -1.1 & 354 & 87 & -0.005 \\
\hline
\end{tabular}

\subsubsection{Värriö-Pallas}

The Värriö-Pallas path included the highest diversity of all observed number size distributions. The clustering procedure resulted in six sets of distributions for the summer and four sets for the winter. In both seasons, the two largest clusters had over 30 elements and were chosen to be studied in more detail.

During both summer and winter, the most frequent cluster had a bimodal structure and no significant change in the total particle number concentration was seen during the transport. During the summer, this insignificant total concentration change was achieved by a small increase of Aitkenmode particle concentration while the accumulation-mode particles decreased. The total particle number concentrations were slightly higher during summer than in winter.

For the second-most frequent cluster, the accumulation mode was the dominant one at Pallas in both summer and winter. During the atmospheric transport, the total particle number concentration decreased with clearly different patterns between the two seasons. During the winter, very similar particle number size distribution arrived at Pallas as had been left from Värriö, indicating the sinks and sources of aerosol particles were in balance. In summer the concentration in the two modes in the accumulation region decreased with a total rate of $0.005 \mathrm{~cm}^{-3} \mathrm{~s}^{-1}$, whereas during winter the accumulation mode remained unaltered and the Aitken mode decreased and shifted to larger sizes with rates of $0.005 \mathrm{~cm}^{-3} \mathrm{~s}^{-1}$ and $0.4 \mathrm{~nm} \mathrm{~h}^{-1}$.

\subsubsection{General remarks}

When comparing the most dominant clusters of each station pair, a clear effect from wind direction became evident. The evolution of the particle modes during transport from west to east resulted in similar changes in the Aitken-mode particles 
Table 5. Dynamics of particle number size distributions when air masses transport from one site to another. Similar to Table 4 , but now covering the winter season.

\begin{tabular}{|c|c|c|c|c|c|c|c|c|}
\hline & \multirow[t]{2}{*}{ Mean $\Delta t$} & \multirow[t]{2}{*}{ Mean RH } & \multicolumn{2}{|c|}{ Mode peak (nm) } & \multirow[t]{2}{*}{$\begin{array}{c}\text { Shift of } \\
\text { mode } \\
\left(\mathrm{nm} \mathrm{h}^{-1}\right)\end{array}$} & \multicolumn{2}{|c|}{$\begin{array}{c}\text { Concentration } \\
\text { of mode } \\
\left(\mathrm{cm}^{-3}\right)\end{array}$} & \multirow[t]{2}{*}{$\begin{array}{l}\text { Concentration } \\
\text { change } \\
\left(\mathrm{cm}^{-3} \mathrm{~s}^{-1}\right)\end{array}$} \\
\hline & & & Abisko & Pallas & & Abisko & Pallas & \\
\hline \multirow[t]{4}{*}{ Cluster 1} & $8 \mathrm{~h}$ & $79 \%$ & 26 & 24 & -0.2 & 130 & 223 & 0.003 \\
\hline & & & & 83 & & & 47 & \\
\hline & & & 130 & 169 & 4.9 & 68 & 11 & -0.002 \\
\hline & & & Pallas & Värriö & & Pallas & Värriö & \\
\hline \multirow[t]{3}{*}{ Cluster 1} & $16 \mathrm{~h}$ & $76 \%$ & & 15 & & & 164 & 0.003 \\
\hline & & & 33 & 66 & 2.1 & 110 & 317 & 0.004 \\
\hline & & & 169 & 206 & & 44 & 34 & \\
\hline \multirow[t]{4}{*}{ Cluster 2} & $10 \mathrm{~h}$ & $83 \%$ & 7 & 12 & & 22 & 19 & \\
\hline & & & 59 & 76 & 1.7 & 347 & 404 & 0.002 \\
\hline & & & 158 & 185 & 2.7 & 557 & 673 & 0.003 \\
\hline & & & Värriö & Pallas & & Värriö & Pallas & \\
\hline \multirow[t]{3}{*}{ Cluster 1} & $27 \mathrm{~h}$ & $80 \%$ & 12 & 13 & & 33 & 8 & \\
\hline & & & 46 & 46 & 0.0 & 128 & 115 & -0.000 \\
\hline & & & 202 & 193 & -0.3 & 109 & 127 & -0.001 \\
\hline \multirow[t]{3}{*}{ Cluster 2} & $19 \mathrm{~h}$ & $81 \%$ & 15 & 20 & 0.3 & 47 & 50 & \\
\hline & & & 50 & 57 & 0.4 & 444 & 202 & 0.003 \\
\hline & & & 185 & 186 & 0.1 & 435 & 490 & 0.000 \\
\hline
\end{tabular}

between the stations. During the summer period, the mode peak diameter increased at rates between 0.6 and $1.3 \mathrm{~nm} \mathrm{~h}^{-1}$ and the concentration of the mode increased at rates of $0.01-$ $0.02 \mathrm{~cm}^{-3} \mathrm{~s}^{-1}$. When looking at the corresponding summertime clusters for the opposite transport direction, the concentration changes of the Aitken mode were not as intense (rates between -0.001 and $0.002 \mathrm{~cm}^{-3} \mathrm{~s}^{-1}$ ) and the shifts in the peak diameter of the Aitken mode were small (between $-0.3 \mathrm{~nm} \mathrm{~h}^{-1}$ and $0.2 \mathrm{~nm} \mathrm{~h}^{-1}$ ). During the winter the general pattern was similar, even though the concentration increases were several times weaker compared to the summer.

The differences in the aerosol population and dynamics along the wind direction can be related to two factors. First, the western side of the measurement sites is limited by the Atlantic Ocean, whereas in the east it is limited to northwestern Russia and hence the continent. It has been shown that clean air from the ocean favors new particle formation and growth (Dal Maso et al., 2007; Sogacheva et al., 2005). During the summer, the air masses connected to the most frequent clusters were fresher for the west-to-east transport than for the opposite direction. When considering the air masses traveling from Abisko to Pallas, the average overland time at Abisko was $18 \mathrm{~h}$; for the air masses traveling from Pallas to Värriö, the average time was $37 \mathrm{~h}$; whereas for the air masses traveling from Pallas to Abisko, the corresponding time at Pallas was $46 \mathrm{~h}$ and at Värriö (for air masses trav- eling from Värriö to Pallas) it was $49 \mathrm{~h}$. This agreed with the initial Aitken-mode peak diameters, which were 29 and $26 \mathrm{~nm}$ at Abisko and Värriö, respectively, whereas for the opposite transport direction they were 63 and $53 \mathrm{~nm}$ at Värriö and Pallas, respectively. When the air mass was coming from the continent, it had a larger condensation sink which likely hindered the formation of new particles. Secondly, the wind direction was associated with different meteorological conditions. We calculated the relative humidity along the trajectories between the measurement station pairs. For the summer time, the median values of relative humidity for each cluster associated with the west-to-east paths were between 72 and $78 \%$, whereas for the opposite paths they were between 81 and $85 \%$. The higher relative humidity values have been connected to lower NPF probabilities e.g., at Pallas (Asmi et al., 2011).

During both seasons and for both wind directions, the second-most frequent clusters included a strong accumulation mode at the upwind station, and the same mode also dominated in the downwind station. This was presumably because accumulation-mode particles have the longest lifetime in atmosphere.

The observed shifts in the diameter of the Aitken-mode peak were around $1 \mathrm{~nm} \mathrm{~h}^{-1}$ during the summer period. This was close to the value of the apparent growth rates obtained when studying the particle evolution when they travel over 

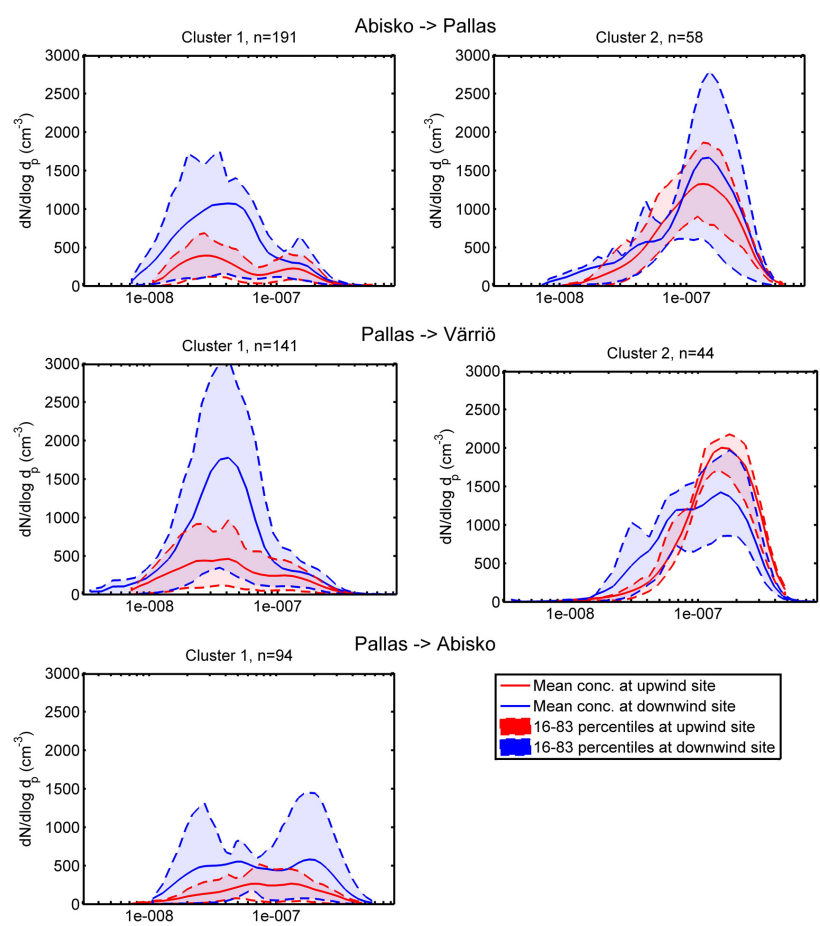

Pallas -> Abisko

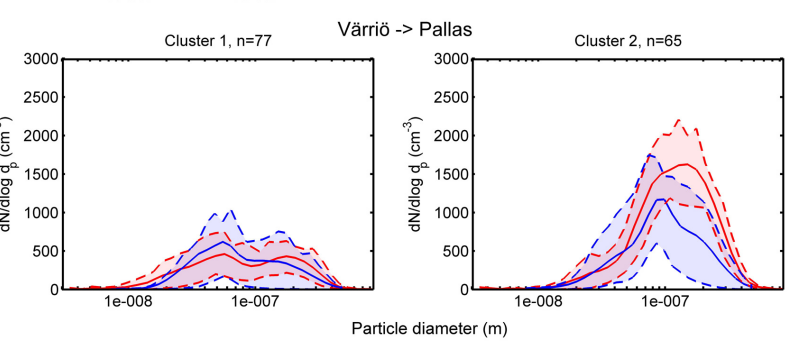

Fig. 9. The dynamics of the particle number size distributions when air masses were moving from one measurement site to another. Summer season 1.4.-30.9 covered. The initial size distributions at the upwind station were clustered to obtain as similar initial states as possible. Each subplot represents one cluster. The first member of the site pair is the upwind site, and the second member is the downwind site. For each cluster, the mean number size distribution at the upwind station is plotted with solid red line, and the shadowed red area shows the 16-83th percentiles. Similarly, the blue solid line is the mean of the corresponding size distributions at the downwind station, and shaded blue area shows the above-mentioned percentiles. The number $\mathrm{n}$ shows the amount of size distribution pairs in each cluster.

land. Again, this was about one-third of the average growth rate observed during NPF events. The increase rates of the Aitken-mode particles were up to $0.02 \mathrm{~cm}^{-3} \mathrm{~s}^{-1}$. When comparing this with the average formation rates during NPF events, we saw that the latter were five times larger. These differences reflect the choice of the data behind the values and stress that the growth and formation rates observed only during the most obvious nucleation days can give misleading numbers of the changes of the total aerosol population.
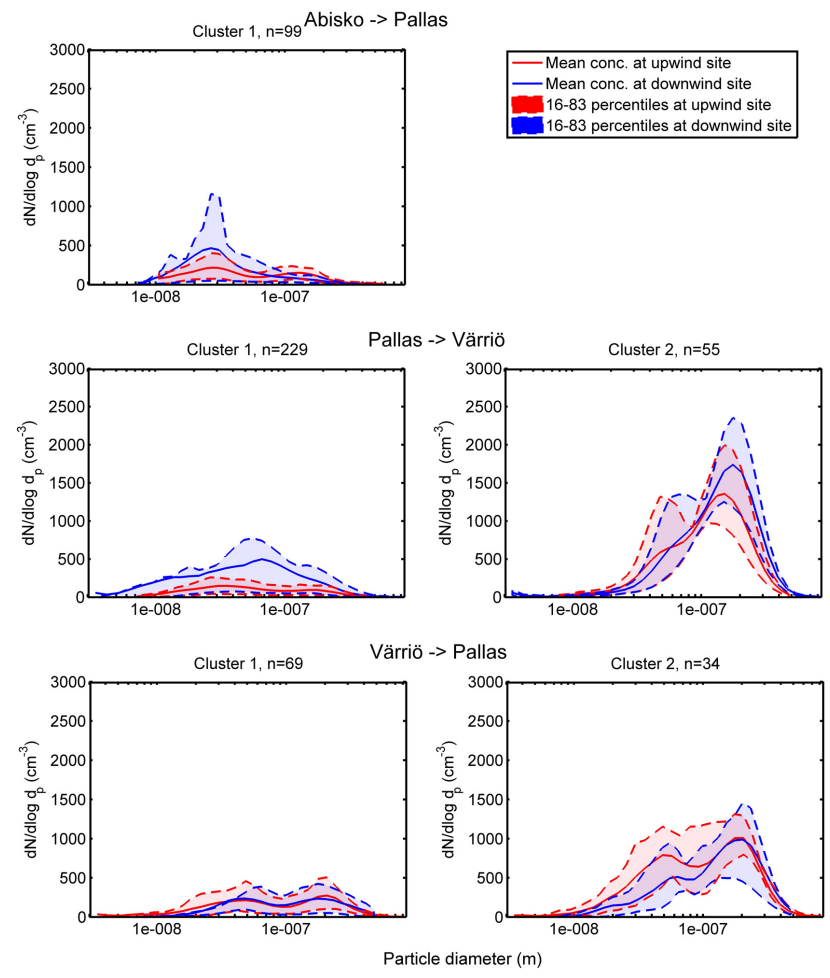

Fig. 10. The dynamics of the number particle size distributions when air masses were moving from one measurement site to another. Similar to Fig. 9, but covering the winter season, 1.10-31.3.

The vast majority of the land area between Pallas and Abisko is inhabited and covered by boreal forest. Inside the possible trajectory sector, we estimated the Kiruna mining town to be the most potent anthropogenic source that might influence the aerosol population. Our trajectory analysis showed that, of the trajectories used for the clusters between Abisko and Pallas, (both ways), only 0-8\% passed Kiruna closer than $15 \mathrm{~km}$ away, so this town is unlikely to have significantly affected the results.

The fractions of considered trajectories that were within the mixing boundary layer at the upwind station during the transport from the upwind to the downwind station were the following: from Abisko to Pallas $97 \%$, from Pallas to Abisko $87 \%$, from Pallas to Värriö $94 \%$ and from Värriö to Pallas $98 \%$. We therefore conclude that in the vast majority of cases, the airflow was also connected vertically.

\section{Summary and conclusions}

Three different approaches for the nucleation and growth of aerosol particles in northern Scandinavia gave mutually supportive information on the evolution of the aerosol population. When studying the average air masses arriving at the different stations, we found that the apparent increase rates of particle mode diameters, accumulated mass concentrations, 
and condensation sinks displayed a similar behavior between all the stations. During the summer period, Värriö had the largest rates for the mass concentration increase and condensation sink increase, while these two quantities were rather similar for the other two stations. Abisko station differs from Pallas and Värriö with respect to its environment by being surrounded by mountains and the ocean; Pallas is situated above the tree line on the top of a fell, which is sometimes in the clouds, while Värriö is also located on a hill, but inside a boreal forest. The result can be interpreted that the footprint of aerosols is large, which flattens the differences resulting from the near and mid-scale surroundings. At a large scale, all the stations are situated in the boreal forest zone, which has its characteristic biological emissions from soil and vegetation. During the summer period, the NPF event day probability peaked at overland times of $20-25 \mathrm{~h}$ in Värriö and Pallas, and this number size distribution was flat in Abisko, but this difference was not seen to have an effect on the apparent particle growth rates.

Due to this large-scale homogeneity of the aerosol processes over northern Scandinavia, the effect of wind directions on the aerosol dynamics between site pairs could be studied separately. Western air masses arriving from ocean have previously been connected to an increased NPF event probability (e.g., Dal Maso et al., 2007). Our study supports this view by showing that during the summer season, both of the transport routes from the west-to-east direction showed an intensifying Aitken mode with an increase in both particle size and concentration. No such phenomenon was observed for the opposite air mass transport direction. Since changes in the Aitken mode were considerably weaker during the winter time, the result supported the assumption that biogenic volatile emissions were linked to the particle growth.

We found that during the summer season, the Aitken-mode particles grew at an apparent rate of $1 \mathrm{~nm} \mathrm{~h}^{-1}$ or less during the air mass transport. The average apparent growth rates of Aitken-mode particles were between 0.55 and $0.72 \mathrm{~nm} \mathrm{~h}^{-1}$ when looking at air masses arriving from the ocean at the individual stations, and in the range of $0.5-1.3 \mathrm{~nm} \mathrm{~h}^{-1}$ when looking at air masses transported between two stations. Both these rates were found to be several times smaller than average particle growth rates during NPF events. This indicates that during the summer season, the condensational growth has an important effect in the regional-scale air masses also when the evident nucleation, i.e. "banana curve", is not observed. Also, when the air masses were traveling from west to east from site to site during the summer period, the air masses for the most frequent clusters at initial site had been overland less than $40 \mathrm{~h}$ on average. The Aitken-mode particle concentration increase rates of these clusters were of order of magnitude of $0.01 \mathrm{~cm}^{-3} \mathrm{~s}^{-1}$; this agrees with the apparent particle concentration increase rate with the overland times of below 30-40 $\mathrm{h}$ above the continent.

During the atmospheric transport, the net effect of the source and sink processes on the particle number concentra- tion depends on the initial aerosol population and its time evolution. The NPF was seen to increase particle number concentrations for overland times up to $30-40 \mathrm{~h}$ or, alternatively, as long as the diameter of the Aitken-mode particles remained below about $40-50 \mathrm{~nm}$. After that, the particle number concentration saturated, which means that NPF was balanced by coagulation and other sink processes. The net accumulation of secondary mass on newly formed and preexisting aerosol particles seemed to continue for at least 4 days of overland transport time.

Acknowledgements. Financial support from the Academy of Finland Centre of Excellence program (project no. 1118615) and the Nordic Centre of Excellence CRAICC (CRyosphere-Atmosphere Interactions in Changing Climate) is gratefully acknowledged.

Edited by: J. Bäck

\section{References}

Asmi, E., Kivekäs, N., Kerminen, V.-M., Komppula, M., Hyvärinen, A.-P., Hatakka, J., Viisanen, Y., and Lihavainen, H.: Secondary new particle formation in Northern Finland Pallas site between the years 2000 and 2010, Atmos. Chem. Phys., 11, 12959-12972, doi:10.5194/acp-11-12959-2011, 2011.

Beddows, D. C. S., Dall'Osto, M., and Harrison, R. M.: Cluster analysis of rural, urban, and curbside atmospheric particle size data, Environ. Sci. Technol., 43, 4694-4700, doi:10.1021/es803121t, 2009.

Covert, D. S., Wiedensohler, A., Aalto, P., Heintzenberg, J., McMurry, P. H., and Leck, C.: Aerosol number size distributions from 3 to $500 \mathrm{~nm}$ diameter in the arctic marine boundary layer during summer and autumn, Tellus B, 48, 197-212, doi:10.1034/j.1600-0889.1996.t01-1-00005.x, 1996.

Dal Maso, M., Kulmala, M., Lehtinen, K., Mäkelä, J., Aalto, P., and O'Dowd, C.: Condensation and coagulation sinks and formation of nucleation mode particles in coastal and boreal forest boundary layers, J. Geophys. Res., 107, 8097, doi:10.1029/2001JD001053, 2002.

Dal Maso, M., Kulmala, M., Riipinen, I., Wagner, R., Hussein, T., Aalto, P. P., and Lehtinen, K. E. J.: Formation and growth of fresh atmospheric aerosols: eight years of aerosol size distribution data from SMEAR II, Hyytiälä, Finland, Boreal Environ. Res., 10, 323-336, 2005.

Dal Maso, M., Sogacheva, L., Aalto, P. P., Riipinen, I., Komppula, M., Tunved, P., Korhonen, L., Suur-Uski, V., Hirsikko, A., Kurtén, T., Kerminen, V.-M., Lihavainen, H., Viisanen, Y., Hansson, H., and Kulmala, M.: Aerosol size distribution measurements at four Nordic field stations: identification, analysis and trajectory analysis of new particle formation bursts, Tellus B, 59, 350-361, doi:10.1111/j.1600-0889.2007.00267.x, 2007.

Draxler, R. R. and Hess, G.: An overview of the HYSPLIT_4 modelling system for trajectories, dispersion, and deposition, Aust. Meteorol. Mag., 47, 295-308, 1998.

Flanner, M. G., Zender, C. S., Hess, P. G., Mahowald, N. M., Painter, T. H., Ramanathan, V., and Rasch, P. J.: Springtime warming and reduced snow cover from carbonaceous particles, 
Atmos. Chem. Phys., 9, 2481-2497, doi:10.5194/acp-9-24812009, 2009.

Hari, P., Kulmala, M., Pohja, T., Lahti, T., Siivola, E., Palva, L., Aalto, P., Hämeri, K., Vesala, T., and Luoma, S.: Air pollution in eastern Lapland: challenge for an environmental measurement station, Silva Fenn., 28, 29-39, 1994.

Hatakka, J., Aalto, T., Aaltonen, V., Aurela, M., Hakola, H., Komppula, M., Laurila, T., Lihavainen, H., Paatero, J., and Salminen, K.: Overview of the atmospheric research activities and results at Pallas GAW station, Boreal Environ. Res., 8, 365-383, 2003.

Heintzenberg, J., Birmili, W., Wiedensohler, A., Nowak, A., and Tuch, T.: Structure, variability and persistence of the submicrometre marine aerosol, Tellus B, 56, 357-367, doi:10.1111/j.1600-0889.2004.00115.x, 2004.

Hussein, T., Dal Maso, M., Petäjä, T., Koponen, I. K., Paatero, P., Aalto, P. P., Hämeri, K., and Kulmala, M.: Evaluation of an automatic algorithm for fitting the particle number size distribution, Boreal Environ. Res., 10, 337-355, 2005.

Jiang, J. H., Eckermann, S. D., Wu, D. L., and Ma, J.: A search for mountain waves in MLS stratospheric limb radiances from the winter Northern Hemisphere: Data analysis and global mountain wave modeling, J. Geophys. Res., 109, D03107, doi:10.1029/2003JD003974, 2004.

Karvosenoja, N., Kangas, L., Kupiainen, K., Kukkonen, J., Karppinen, A., Sofiev, M., Tainio, M., Paunu, V.-V., Ahtoniemi, P., Tuomisto, J. T., and Porvari, P.: Integrated modeling assessments of the population exposure in Finland to primary $\mathrm{PM}_{2.5}$ from traffic and domestic wood combustion on the resolutions of 1 and $10 \mathrm{~km}$, Air Qual. Atmos. Health, 4, 179-188, doi:10.1007/s11869-010-0100-9, 2010.

Kerminen, V.-M., Lihavainen, H., Komppula, M., Viisanen, Y., and Kulmala, M.: Direct observational evidence linking atmospheric aerosol formation and cloud droplet activation, Geophys. Res. Lett., 32, L14803, doi:10.1029/2005GL023130, 2005.

Komppula, M., Lihavainen, H., Hatakka, J., Paatero, J., Aalto, P., Kulmala, M., and Viisanen, Y.: Observations of new particle formation and size distributions at two different heights and surroundings in subarctic area in northern Finland, J. Geophys. Res., 108, 4295, doi:10.1029/2002JD002939, 2003.

Komppula, M., Lihavainen, H., Kerminen, V.-M., Kulmala, M., and Viisanen, Y.: Measurements of cloud droplet activation of aerosol particles at a clean subarctic background site, J. Geophys. Res., 110, D06204, doi:10.1029/2004JD005200, 2005.

Komppula, M., Sihto, S.-L., Korhonen, H., Lihavainen, H., Kerminen, V.-M., Kulmala, M., and Viisanen, Y.: New particle formation in air mass transported between two measurement sites in Northern Finland, Atmos. Chem. Phys., 6, 2811-2824, doi:10.5194/acp-6-2811-2006, 2006.

Koponen, I. K., Virkkula, A., Hillamo, R., Kerminen, V.-M., and Kulmala, M.: Number size distributions and concentrations of marine aerosols: Observations during a cruise between the English Channel and the coast of Antarctica, J. Geophys. Res., 107, 4753, doi:10.1029/2002JD002533, 2002.

Kulmala, M., Suni, T., Lehtinen, K. E. J., Dal Maso, M., Boy, M., Reissell, A., Rannik, Ü., Aalto, P., Keronen, P., Hakola, H., Bäck, J., Hoffmann, T., Vesala, T., and Hari, P.: A new feedback mechanism linking forests, aerosols, and climate, Atmos. Chem. Phys., 4, 557-562, doi:10.5194/acp-4-557-2004, 2004a.
Kulmala, M., Vehkamäki, H., Petäjä, T., Dal Maso, M., Lauri, A., Kerminen, V.-M., Birmili, W., and McMurry, P. H.: Formation and growth rates of ultrafine atmospheric particles: a review of observations, J. Aerosol Sci., 35, 143-176, doi:10.1016/j.jaerosci.2003.10.003, 2004b.

Kulmala, M., Alekseychik, P., Paramonov, M., Laurila, T., Asmi, E., Arneth, A., Zilitinkevich, S., and Kerminen, V.-M.: On measurements of aerosol particles and greenhouse gases in Siberia and future research needs, Boreal Environ. Res., 16, 337-362, 2011.

Kulmala, M., Petäjä, T., Nieminen, T., Sipilä, M., Manninen, H. E., Lehtipalo, K., Dal Maso, M., Aalto, P. P., Junninen, H., and Paasonen, P.: Measurement of the nucleation of atmospheric aerosol particles, Nat. Protoc., 7, 1651-1667, doi:10.1038/nprot.2012.091, 2012.

Lamberg, H., Nuutinen, K., Tissari,J., Ruusunen, J., Yli-Pirilä, P., Sippula, O., Tapanainen, M., Jalava, P., Makkonen, U., Teinilä, K., Saarnio, K., Hillamo, R., Hirvonen, M.-R., and Jokiniemi, J.: Physicochemical characterization of fine particles from small-scale wood combustion, Atmos. Environ., 45, 76357643, doi:10.1016/j.atmosenv.2011.02.072, 2011.

Law, K. S. and Stohl, A.: Arctic Air Pollution: Origins and Impacts, Science, 315, 1537-1540, doi:10.1126/science.1137695, 2007.

Lihavainen, H., Kerminen, V.-M., Tunved, P., Aaltonen, V., Arola, A., Hatakka, J., Hyvärinen, A., and Viisanen, Y.: Observational signature of the direct radiative effect by natural boreal forest aerosols and its relation to the corresponding first indirect effect, J. Geophys. Res., 114, D20206, doi:10.1029/2009JD012078, 2009.

Lu, J. and Cai, M.: Quantifying contributions to polar warming amplification in an idealized coupled general circulation model, Clim. Dynam., 34, 669-687, doi:10.1007/s00382-009-0673-x, 2010.

MathWorks Inc., Matlab Documentation Center: Kmeans clustering [Homepage of Mathworks], [Online], available at: http: //www.mathworks.se/help/stats/kmeans.html (last access: 17 Novermber 2012), 2011.

Nappo, C. J.: An introduction to atmospheric gravity waves, Academic Press, San Diego, California, USA, 47-80, 2002.

O’Dowd, C. D., Facchini, M. C., Cavalli, F., Ceburnis, D., Mircea, M., Decesari, S., Fuzzi, S., Yoon, Y. J., and Putaud, J. P.: Biogenically driven organic contribution to marine aerosol, Nature, 431, 676-680, doi:10.1038/nature02959, 2004.

Paasonen, P., Asmi, A., Petäjä, T., Kajos, M. K., Äijälä, M., Junninen, H., Holst, T., Abbatt, J. P. D., Arneth, A., Birmili, W., van der Gon, H. D., Hamed, A., Hoffer, A., Laakso, L., Laaksonen, A., Leaitch, W. R., Plass-Dülmer, C., Pryor, S. C., Räisänen, P., Swietlicki, E., Wiedensohler, A., Worsnop, D. R., Kerminen, V.-M., and Kulmala, M.: Warming-induced increase in aerosol number concentration likely to moderate climate change, Nat. Geosci., 6, 438-442, doi:10.1038/ngeo1800, 2013.

Ruuskanen, T. M., Reissell, A., Keronen, P., Aalto, P. P., Laakso, L., Gronholm, T., Hari, P., and Kulmala, M.: Atmospheric trace gas and aerosol particle concentration measurements in Eastern Lapland, Finland 1992-2001, Boreal Environ. Res., 8, 335-350, 2003.

Schroeder, S., Preusse, P., Ern, M., and Riese, M.: Gravity waves resolved in ECMWF and measured by SABER, Geophys. Res. Lett., 36, L10805, doi:10.1029/2008GL037054, 2009. 
Scorer, R. S.: Theory of waves in the lee of mountains, Q. J. Roy. Meteor. Soc., 75, 41-56, doi:10.1002/qj.49707532308, 1949.

Screen, J., Deser, C., and Simmonds, I.: Local and remote controls on observed Arctic warming, Geophys. Res. Lett., 39, L10709, doi:10.1029/2012GL051598, 2012.

Shindell, D. and Faluvegi, G.: Climate response to regional radiative forcing during the twentieth century, Nat. Geosci., 2, 294-300, doi:10.1038/ngeo473, 2009.

Sihto, S.-L., Mikkilä, J., Vanhanen, J., Ehn, M., Liao, L., Lehtipalo, K., Aalto, P. P., Duplissy, J., Petäjä, T., Kerminen, V.-M., Boy, M., and Kulmala, M.: Seasonal variation of CCN concentrations and aerosol activation properties in boreal forest, Atmos. Chem. Phys., 11, 13269-13285, doi:10.5194/acp-11-13269-2011, 2011.

Sogacheva, L., Dal Maso, M., Kerminen, V.-M., and Kulmala, M.: Probability of nucleation events and aerosol particle concentration in different air mass types arriving at Hyytiälä, southern Finland, based on back trajectories analysis, Boreal Environ. Res., 10, 479-491, 2005.

Spracklen, D. V., Bonn, B., and Carslaw, K. S.: Boreal forests, aerosols and the impacts on clouds and climate, Philos. T. Roy. Soc. A, 366, 4613-4626, doi:10.1098/rsta.2008.0201, 2008.

Spracklen, D. V., Carslaw, K. S., Pöschl, U., Rap, A., and Forster, P. M.: Global cloud condensation nuclei influenced by carbonaceous combustion aerosol, Atmos. Chem. Phys., 11, 9067-9087, doi:10.5194/acp-11-9067-2011, 2011.

Stohl, A.: Computation, accuracy and applications of trajectories - A review and bibliography, Atmos. Environ., 32, 947-966, doi:10.1016/S1352-2310(97)00457-3, 1998.

Svenningsson, B., Arneth, A., Hayward, S., Holst, T., Massling, A., Swietlicki, E., Hirsikko, A., Junninen, H., Riipinen, I., and Vana, M.: Aerosol particle formation events and analysis of high growth rates observed above a subarctic wetland-forest mosaic, Tellus B, 60, 353-364, doi:10.1111/j.1600-0889.2008.00351.x, 2008.
Tunved, P., Korhonen, H., Ström, J., Hansson, H.-C., Lehtinen, K. E. J., and Kulmala, M.: A pseudo-Lagrangian model study of the size distribution properties over Scandinavia: transport from Aspvreten to Värriö, Atmos. Chem. Phys. Discuss., 4, 7757-7794, doi:10.5194/acpd-4-7757-2004, 2004.

Tunved, P., Hansson, H. C., Kerminen, V.-M., Ström, J., Maso, M. D., Lihavainen, H., Viisanen, Y., Aalto, P., Komppula, M., and Kulmala, M.: High natural aerosol loading over boreal forests, Science, 312, 261-263, doi:10.1126/science.1123052, 2006 a.

Tunved, P., Korhonen, H., Ström, J., Hansson, H. C., Lehtinen, K., and Kulmala, M.: Is nucleation capable of explaining observed aerosol integral number increase during southerly transport over Scandinavia?, Tellus B, 58, 129-140, 2006b.

Tunved, P., Ström, J., Kulmala, M., Kerminen, V.-M., Dal Maso, M., Svenningson, B., Lunder, C., and Hansson, H. C.: The natural aerosol over northern Europe and its relation to anthropogenic emissions - implications of important climate feedbacks, Tellus B, 60, 473-484, doi:10.1111/j.1600-0889.2008.00363.x, 2008.

Vehkamäki, H., Dal Maso, M., Hussein, T., Flanagan, R., Hyvärinen, A., Lauros, J., Merikanto, P., Mönkkönen, M., Pihlatie, K., Salminen, K., Sogacheva, L., Thum, T., Ruuskanen, T. M., Keronen, P., Aalto, P. P., Hari, P., Lehtinen, K. E. J., Rannik, Ü., and Kulmala, M.: Atmospheric particle formation events at Värriö measurement station in Finnish Lapland 1998-2002, Atmos. Chem. Phys., 4, 2015-2023, doi:10.5194/acp-4-2015-2004, 2004. 